\title{
WOMEN ON COMPANY BOARDS: EQUALITY MEETS SUBSIDIARITY
}

\author{
Barbara Havelková*
}

\begin{abstract}
$\underline{\text { Abstract }}$
This paper explores the justifications for and objections to the proposed European Union 'women on company boards' Directive. It notes that Member State opposition to the measure had different emphases. Those new, post-socialist Member States which intervened prominently questioned the Commission's understanding of the underlying social reality of gender inequality and the measure's focus on results, while the old Member States which intervened raised mainly the issue of subsidiarity and challenged the need for legislative action, and/ or particularly the need for legislative action at EU level. The paper further argues that the Commission weakened its case by emphasising economic rationales for the measure, and submits that a principled justification fits the proposal better. Finally, the paper argues that subsidiarity-related arguments are available also to justify non-cross-border, non-economic projects, such as that of gender equality.
\end{abstract}

\footnotetext{
* Shaw Foundation Fellow in Law, Lincoln College and Faculty of Law, University of Oxford; barbara.havelkova@law.ox.ac.uk. I would like to thank Cristina Chiva for a stimulating conversation at UACES conference in 2013, which originally sparked my interest in the role of subsidiarity in this area. I would like to thank the J ean Monnet and Hauser Global community at NYU for comments on the research project (September 2016), and the participants of the lunchtime seminar at the Cambridge Centre for European Legal Studies (November 2017) and the Oxford Socio-Legal Discussion Group (December 2017) for fruitful discussions of earlier versions of the paper. I would also like to thank Sandra Fredman, Steve Weatherill, Kenneth Armstrong, Elena Brodeala, Mathias Möschel and two anonymous reviewers for comments on earlier drafts, as well as Surabhi Shukla for research assistance, and Kalina Arabadjieva for careful editing at the final stage. The usual disclaimer applies. The paper reflects the legal situation as of end of November 2018.
} 


\section{INTRODUCTION}

In 2012, the European Commission presented a proposal of the Directive on improving the gender balance among non-executive directors of companies listed on stock exchanges and related measures ('Proposal'). ${ }^{1}$ The Proposal is novel, interesting and controversial for several reasons. ${ }^{2}$ Firstly, although not prescribing a hard quota, it arguably adopts a results-oriented approach to equality, which opens the question of what understanding of equality can be said to inform it. Secondly, it enters into a complex field of corporate governance which challenges the harmonisation project due to the very varied national structures. Thirdly, it moves beyond the field of employment which - considering its legal basis (Art 157 TFEU) - raises constitutional questions of competence and subsidiarity. Finally, it comes against the background of the stalled proposal to extend the prohibition of discrimination on the basis of religion or belief, disability, age or sexual orientation beyond the labour market, ${ }^{3}$ which leads to the question of why the Commission went ahead with this Proposal.

The Directive has met with considerable opposition. By the deadline in J anuary 2013, eleven domestic chambers sent reasoned opinions ${ }^{4}$ and further five sent comments. ${ }^{5}$ This falls short of the requirement of a third of national parliaments to express concerns over compliance with the principle of subsidiary, necessary for triggering the 'yellow card' mechanism under the Subsidiarity Protocol, but it shows a reasonable amount of push-back. The Proposal has also lacked persuasive support in

\footnotetext{
1 The full details of the Proposal and its journey through the legislative process can be found at $<$ http:// www.europarl.europa.eu/ oeil/popups/ ficheprocedure.do?reference=2012/ 0299\%28COD\%2 9\&l=en $>$ accessed 25 May 2018.

2 I thank Sandra Fredman for a useful conversations about the question of novelty.

3 Proposal for a Council Directive on implementing the principle of equal treatment between persons irrespective of religion or belief, disability, age or sexual orientation. SEC(2008) 2181 $/ * \mathrm{COM} / 2008 / 0426$ final - CNS 2008/0140*/ available at <https:// eur-lex.europa.eu/legalcontent/en/TXT/ ?uri=CELEX\%3A52008PC0426 > accessed 25 May 2018. A summary of the stage of adoption (stalled in Council) and the reasons for the objections to it are helpfully summarized by the European Parliament here: <http:// www.europarl.europa.eu/legislative-train/theme-area-of-justiceand-fundamental-rights/ file-anti-discrimination-directive> accessed 6 December 2018.

${ }^{4}$ In order to acknowledge the diverse domestic parliamentary structures, which are sometimes unicameral and sometimes bicameral, each MSs has two 'votes' in the process. Counted like this, out of the 56 votes available, 11votes were 'cast' via a reasoned opinion: Czech Chamber of Deputies (1), Danish Folketing (2), the Dutch Senate and House of Representatives (2), the Polish Sejm and Senate (2), the Swedish Riksdag (2) and the UK's House of Commons and House of Lords (2). The communications are available on the website of IPEX (The platform for EU Interparliamentary Exchange) $<$ http:// www.ipex.eu/ IPEXL-

WEB/ dossier/ dossier.do?code=COD\&year=2012\&number=0299\&appLng=EN $\geq$ accessed 25 May 2018.

${ }^{5}$ Czech Senate (1), Estonian Parliament (1), French Senate and National Assembly (2), Romanian Chamber of Deputies (1).
} 
the Council. ${ }^{6}$ At the moment, having been approved by the European Parliament at first reading, the Proposal is awaiting the first reading position of the Council. ${ }^{7}$ Whether or not the Directive gets adopted, the discussion it has generated - on the interaction between the EU value and aim of gender equality on the one hand and the constitutional demands of EU's multi-level system, in particular the principles of conferral, proportionality and especially subsidiarity on the other - is worth critically examining.

The paper asks two questions. First, on what grounds did the Member States ('MSs') object to the Proposal? Were their objections about subsidiarity or were they substantive in nature, challenging specific aspects of the measure or even the project of gender equality more generally? Second, as far as subsidiarity is concerned, do the MSs' objections indicate an in-built incompatibility between subsidiarity and noncross-border, non-economic projects, such as that of gender equality?

Answering the first question, I note that different MSs had different emphases. The four new, post-socialist Central and Eastern European ('CEE') $\mathrm{MSs}^{8}$ whose national parliaments submitted reasoned opinions or comments, ${ }^{9}$ aside from raising other objections, appeared to prominently and emphatically disagree with some of the fundamental premises of EU anti-discrimination law, especially as far as the underlying social reality is concerned, as well as the measure's focus on results. The

\footnotetext{
${ }^{6}$ It has been reported that the proposal has been 'blocked by Germany, the Netherlands and Sweden overs fears that Brussels was overreaching into domestic affairs. Hungary and Poland have opposed the move on ideological grounds.' The Guardian, EU to push for $40 \%$ quota for women on company boards (20 November 2017) <https:// www.theguardian.com/world/2017/nov/20/eu-to-push-for-40-quotafor-women-on-company-boards>accessed 6 December 2018.

${ }^{7}$ It was most recently debated in the Council in J une 2017. The legislative progress of the proposal can be tracked at

$<$ http:// www.europarl.europa.eu/ oeil/popups/ ficheprocedure.do?reference=2012/ 0299\%28COD\%2

$9 \& \mathrm{~d}=\mathrm{en}>$ accessed 6 December 2018. For a more detailed analysis of the development, see egJ ulie

Suk, Democratic Deficits and Gender Quotas: The Evolution of the Proposed EU Directive on Gender Balance on Corporate Boards (The Foundation for Law, J ustice and Society 2014).

${ }^{8}$ I used the term 'post-socialist' to refer to the Central and Eastern European countries which emerged from state socialism in the last two decades of the $20^{\text {th }}$ century. When I speak of 'post-socialist' or 'new' MSs in this paper, I refer to those whose parliaments expressed themselves on the Proposal (Czechia, Poland, Estonia, and Romania). The argument about the relative hostility of new, post-socialist MSs to gender equality, presented here, however, applies to them more widely. I do not elaborate here for reasons of space, but I have discussed this in greater detail elsewhere. See Barbara Havelková, Gender Equality in Law: Uncovering the Legacies of Czech State Socialism (Hart/Bloomsbury 2017), esp 2-3 and references therein.

${ }_{9}^{9}$ Czechia, Estonia, Poland, and Romania.
} 
five old MSs whose chambers submitted reasoned opinions or comments, ${ }^{10}$ on the other hand, primarily focused on subsidiarity and challenged Commission evidence that action at domestic level was insufficient and EU-level action was required. In the new MSs' understanding, there are not enough women who are good enough for company boards (because of a historical educational gender gap and because they are deemed not to be meritorious enough), the inequality is a consequence of women's life choices (notably motherhood), and markets naturally push companies toward meritocracy. Any inequality is thus perceived as natural or justified, and law should therefore not do anything about it ${ }^{11}$ - neither domestically ${ }^{12}$ nor at EU level. The new MSs were also critical of any measure focusing on results, viewing it as discriminatory.

The Commission and most of the five old Member States which intervened, on the other hand, did not question the existence of structural obstacles to the advancement of women, nor their injustice. Nor did they challenge the assertion that an intervention might be appropriate. The disagreement between the Commission and these old MSs was rather mainly about the exact form that legislative action should take, ${ }^{13}$ whether legislative action is necessary or self-regulation suffices, and whether there is need for legislative action at the EU level.

It is perhaps worth noting from the get-go that my concern is not about the fact that the new MSs used the Subsidiarity Protocol for a political and policy debate rather than merely to address the 'technical' question of subsidiarity. This use of the Subsidiarity Protocol for contestation of legislative substance has been a wider trend. ${ }^{14}$

\footnotetext{
${ }^{10}$ Denmark, France, Netherlands, Sweden, and the UK.

${ }^{11}$ Deborah Rhode has described the failure to recognize the seriousness of gender inequality as the "no problem" problem'. She notices three patterns: 1) the denial of gender inequality; 2) the denial of injustice; and 3) the denial of responsibility. The latter two are prominent here. See Deborah Rhode, Speaking of Sex: Denial of Gender Inequality (Harvard University Press 1997). I have previously noted that all three are very prominently present in the Czech legal discourse: Havelková, Gender Equality (see note 11) 113-6, 282-5.

${ }^{12}$ In most post-socialist countries, there is no home-grown debate about tackling the gender-imbalance. Initiatives have come neither from business nor from the government.
}

${ }^{13}$ Some scepticism of legislative 'quota' was apparent also in a Report by the UK's House of Lords, which preferred a business-led model. It stated that they might 'generate negative perceptions amongst women and business leaders and do not address the root causes of inequality', but the Committee was very careful to stress that the perception that women on boards were not there by merit would be 'entirely incorrect'. House of Lords. European Union Committee, 'Women on Boards. 5th Report of Session 2012- 13 (HL Paper 58)' <http:// www.ipex.eu/ IPEXLWEB/ dossier/files/download/ 082dbcc53af8a96e013b235610641bf8.do>accessed 26 May 2018, 4, 27.

${ }^{14}$ See eg Diane Fromage and Valentin Kreilinger, National Parliaments' Third Yellow Card and the Struggle over the Revision of the Posted Workers Directive' (2017) 10 European Journal of Legal 
Davor J ančić, based on his analysis of the 'yellow card' procedures in other areas, has noted that 'subsidiarity appraisals have de facto evolved into wholesome probes of EU legislative proposals'. ${ }^{15}$ This development is arguably welcome, since it allows national parliaments to use their 'most central competences: the rendering of political judgement about the preferences and interests to be upheld by law'. ${ }^{16}$

My point is rather that in relation to the debate around gender equality, the disagreement - coming from post-socialist MSs - does not seem to be 'within the practice' but rather 'about the practice'. ${ }^{17}$ At least some of their objections pose a more fundamental challenge to the 'common value' and central aim of equality between men and women, in particular to a more substantive understanding of equality. 18 The Commission did not seem to realize that the Proposal might have needed two different conversations: one on corporate governance, mainly with the old Member States, and one on gender equality, mainly with the new ones.

In response to the second question, I note that rather than justify the measure first and foremost in terms of the EU's value and aim of equality of men and women, the Commission focused on providing economic rationales for the Proposal. It used this to justify regulatory intervention per se, by claiming that the measure will improve financial performance, as well as to justify regulatory intervention at the EU level, by using internal market logic to highlight cross-border difficulties caused by divergent rules. I observe that neither is a fit for the Proposal. The measure's aim is much better understood as value-based and principled, focusing on increasing women's participation in economic decision-making. Furthermore, I argue that the Commission could have shown that the demands of subsidiarity could be met, even

\footnotetext{
Studies 125, and Irene Wieczorek, The EPPO Draft Regulation Passes the First Subsidiarity Test: An Analysis and Interpretation of the European Commission's Hasty Approach to National Parliaments' Subsidiarity Arguments' (2015) 16 German Law J ournal 1247.

${ }^{15}$ Davor Jančić, 'The Game of Cards: National Parliaments in the EU and the Future of the Early Warning Mechanism and the Political Dialogue' (2015) 52 Common Market Law Review 939, 961.

16 ibid 960.

${ }^{17}$ To borrow Charles Beitz's terminology regarding human rights: Charles Beitz, The Idea of Human Rights (OUP 2009)

${ }_{18}$ Scholars of equality and anti-discrimination law often distinguish between 'formal' and 'substantive' equality. Formal equality emphasizes equal treatment, impartiality, consistency, and asks that decisions be made without regard to a specifically protected characteristic, such as sex. Substantive equality takes context into account, recognizing that the equal treatment of people unequally situated can lead to injustice. It includes measures that aim at equality of opportunity, resources or results. Havelková, Gender Equality (see note 11) 85 and the references therein, esp Sandra Fredman, Discrimination Law (Oxford University Press 2011) 2, 14-19.
} 
admitting that the measure primarily sets minimum domestic standards. I argue that while the wording of Art 5(3) TEU, notably 'scale and effects', might at first sight appear to favour cross-border and economic justifications, this is not the case.

Since the Proposal falls within the EU's fundamental rights competence, I also tentatively assess whether there are specific subsidiarity considerations for such measures. I note that the international human rights law understanding of subsidiarity is not helpful in determining EU subsidiarity. The former only looks at the role of courts and a review of failure rather than standard-setting, which leads to a conclusion about a very limited role for action at the international level. The EU, on the other hand, was specifically given the power to act via legislation. Moreover, one of the reasons advanced for the limited role of the international level - democratic legitimacy of the domestic level - seems to be particularly weak when speaking about fundamental rights, which are counter-majoritarian in nature; and in particular equality and anti-discrimination rights, which specifically have as their aim the improvement of the situation of disadvantaged minorities.

The paper thus contributes to existing literature on subsidiarity and the Proposal ${ }^{19}$ in two ways. First, it offers a more detailed analysis of the content of the national parliaments' objections, especially those coming from some of the postsocialist countries which question the EU's approach to gender equality. Second, it presents a more normative analysis of how to substantiate the subsidiarity of measures beyond cross-border situations.

The paper's organisation follows the five types of objection raised by national parliaments, ${ }^{20}$ relating to: equality (section I), right to ownership and freedom of enterprise (section II), legal basis (section III), proportionality (section IV), and subsidiarity (section V). The final section (VI) looks at the considerations which should

\footnotetext{
${ }^{19}$ The fact that the question of competence in relation to the Proposal is contentious is exemplified not only by the reasoned opinions and comments submitted by national parliaments, but also by secondary literature which has examined it. For a view that the Proposal is in breach of conferral, subsidiarity and proportionality, see Marek Szydlo, 'Constitutional Values Underlying Gender Equality on the Boards of Companies: How Should the EU Put these Values into Practice?' (2014) 63 International and Comparative Law Quarterly 167. For a supportive stance, see Linda Senden, 'Getting Women on Company Boards in the EU: A Tale of Power-Balancing in Three Acts' in Nada Bodiroga-Vukobrat, Siniša Rodin and Gerald G Sander (eds), New Europe - Old Values? (Springer International 2016). ${ }^{20}$ Since all the documents are available on the IPEX website (see fn 4 above), I do not provide individual links when citing them below.
} 
guide the application of the subsidiarity test in cases where the EU uses its fundamental rights competence to set domestic standards.

\section{EQUALITY}

\section{A. The Proposal}

The Proposal aims to increase the participation of women (although it refers to the 'under-represented sex'21) in economic decision-making, which has seen almost no improvement in recent years. ${ }^{22}$ The Proposal sets a minimum objective of a $40 \%$ presence of the under-represented sex among the non-executive directors in companies listed on stock exchanges which are not of small or medium size. ${ }^{23}$ It requires the companies not fulfilling the $40 \%$ to introduce pre-established, clear, neutrally formulated and unambiguous selection criteria for these positions, in order to achieve the $40 \%$ by 1 J anuary 2020 . According to the Commission, the Proposal thus creates an 'obligation of means' rather than of a 'target to attain'. ${ }^{24}$ In other words while an ultimate desired result is stated, the Directive does not create an obligation as to results. The sanctions for non-fulfilment are mostly left to Member States. ${ }^{25}$ Following the CJEU's restrictive case-law on positive action, ${ }^{26}$ which only accepts

\footnotetext{
${ }^{21}$ The Preamble makes clear its concern is with improving the representation of women, but the Articles of the Proposal use gender-neutral language.

22 See eg Linda Senden and Mirella Visser, 'Balancing a Tightrope: The EU Directive on Improving the Gender Balance among Non-Executive Directors of Boards of Listed Companies' [2013] European Gender Equality Law Review 17, 18-20. Unsurprisingly, greatest gains world-wide have recently been made in Western Europe, in connection with various forms of regulation of women's representation. Egon Zehnder International, 2016 Global Board Diversity Analysis (2017) <https:// www.gbda.online/ assets/EZ_2016GBDA_DIGITAL.pdf> accessed 6 December 2018.

${ }^{23}$ Small and medium-sized enterprises (SMEs) are determined by the combined criteria of staff headcount and either turnover or balance sheet total. The 2012 Proposal would only apply to companies with more than 250 employees with a turnover of over 50 million EUR and a balance sheet total over 43 million EUR. For the definition of SMEs, see Commission Recommendation of 6 May 2003 concerning the definition of micro, small and medium-sized enterprises (Text with EEA relevance) (notified under document number C(2003) 1422).

${ }^{24}$ This is language employed by the European Commission in its letter to Denmark's Folketing from 17 J uly 2013, in reaction to its reasoned opinion.

25 Under the Commission version of the Proposal, this was entirely the case. The EP added a requirement of transparent and open procedures and obliged the MSs to react to the failure to implement them, by at least excluding them from public calls for tenders and partial exclusion from the funding from Union's Structural Funds. See Suk (see note 7) 7.

${ }^{26}$ See esp C-409/95 Marschall v Land Nordrhein-Westfalen [1997] ECR I-6363; since the Proposal is based on Art 157, which allows action to be taken in the areas of employment and occupation, it had to abide by the case-law of the CJ EU on positive action in the area employment.
} 
'tipping point' or 'tie-break' measures, ${ }^{27}$ the Proposal only allows 'priority [to be] given to the candidate of the under-represented sex if that candidate is equally qualified.., unless an objective assessment, taking account of all criteria specific to the individual candidates, tilts the balance in favour of the candidate of the other sex.'28

The Proposal thus has limited scope in terms of companies covered, and presents a reasonably light-touch regulation, since much is left to companies and the Member States. And considering the emphasis on process over target, as well as the limited 'tie-break' preference it allows for, it is a very mild way of pushing for greater representation of women in economic decision-making. Despite this, many postsocialist MSs objected to it, not primarily for reasons of subsidiarity, but mainly because of a more fundamental disagreement with such a gender equality project.

\section{B. National parliaments' objections}

The new MSs whose chambers intervened on the Proposal challenged both the problem (insufficient representation of women being unjust and discriminatory, rather than just a fact of life), as well as the solution (a results-oriented approach), and with it, certain facets of the EU's understanding of its avowed central value and aim of equality between men and women ${ }^{29}$ (substantive equality which allows for asymmetry).

\section{The problem}

As for understanding the problem, in some of the new MSs' view, exemplified below especially by the Czech position, there are not (yet) enough women who are good enough for company boards, the inequality is a consequence of women's life choices (notably motherhood) and therefore justified. This, combined with a belief that merit

\footnotetext{
${ }^{27}$ For how a 'tie-break' fits in with other types of positive action, see Christopher McCrudden, 'A Comparative Taxonomy of 'Positive Action' and 'Affirmative Action' Policies' in Reiner Schulze (ed), Non-Discrimination in European Private Law (Mohr Siebeck 2011). ${ }^{28}$ Art 4(3) of the Commission's Proposal; Art 4(1) of the EP's Proposal.

${ }^{29}$ Contained in Art 2 and 3 TEU.
} 
is defined and applied gender-neutrally, leads them to conclude that regulation is not needed - neither domestically ${ }^{30}$ nor at EU level. Let us look at these points in detail.

In its reasoned opinion, the Czech Senate highlighted 'the high age of supervisory board members' which is then related to 'the absence of women in those segments of senior management of companies, from which members of supervisory boards are generally recruited'. This comment is interesting coming from a postsocialist country where the numbers of women university graduates surpassed the 40 \% mark in the 1980s. ${ }^{31}$ But the importance of this comment is conceptual. Taken together with the following observation, that because of motherhood, women lag behind men in their career development', it shows an easy acceptance of sex inequality as a fact of life. The Senate shows that it does not consider inequalities between the sexes an injustice. It also omits to consider the barriers women face irrespective of whether or not they are mothers.

When the Senate then says that legislative initiatives of the European Commission should primarily focus on removing barriers that prevent women from realizing their full potential in our society', they show a lack of understanding that, especially limited 'tie-break' positive measures, can do exactly that. Sheryl Sandberg's book Lean In ${ }^{32}$ popularised a piece of research which showed that men apply for a job when they meet only $60 \%$ of the qualifications, but women apply only if they meet $100 \%$ of them. ${ }^{33}$ Sandberg herself identified this as a lack of confidence. This has been criticized for not sufficiently recognizing that even when women overcome their lack of confidence, they can be punished for having it: research has shown that women who initiated negotiations for higher compensation were penalized more than men. ${ }^{34}$

\footnotetext{
${ }^{30}$ In most post-socialist countries, there is no home-grown debate about tackling the gender-imbalance. Initiatives have come neither from business nor from the government.

${ }^{31}$ The percentage of women among university graduates rose from $20 \%$ in 1950 to $34 \%$ in 1960 and to $44 \%$ in 1987. Sharon L Wolchik, 'Ideology and Equality' (1981) 13 Comparative Political Studies 445, 449. For a more general discussion of the situation of Czechoslovak women during state socialism, see Havelková, Gender Equality (see note 11).

${ }^{32}$ Arguably, her book only came after the deadline for national parliament's reasoned opinions, but the research which informed the debate on barriers to women's entry had existed for years before then. Sheryl Sandberg, Lean In: Women, Work, and the Will to Lead (Alfred A Knopf 2013).

33 A helpful summary and links to the original research are presented in Tara Sophia Mohr, Why Women Don't Apply for J obs Unless They're 100\% Qualified', Harvard Business Review (25 August 2014) <https:// hbr.org/ 2014/ 08/ why-women-dont-apply-for-jobs-unless-theyre-100-qualified> accessed 26 May 2018.

${ }^{34}$ A good summary of the research by Hannah Riley Bowles is available in Maria Konnikova, 'Lean Out:

The Dangers for Women who negotiate', The New Yorker (20 June 2014)
} 
Others have pointed out that the low number of women is in part due to their lack of understanding of how hiring processes really work. ${ }^{35}$ Women are socialized to believe that there is a need to respect rules and also to believe in the importance of formal qualifications over advocacy and networking. 36 Moreover, 'men are often hired or promoted based on their potential, women for their experience and track record', and research suggests that women's failures are remembered longer than men's. ${ }^{37}$

This shows that the barriers consist of a combination of external factors women are subject to a different standard - as well as their internal assessment of themselves and their chances. The latter is partly based on experience, partly on years of negative socialization as far as ambition and confidence is concerned. They are a systematic rather than an individual problem. Women's behaviour is thus not accidental and their perceptions are not irrational. This suggests that explicitly stating that women are expected to be present and that they are wanted, as the Proposal does, might go a long way to actually 'removing barriers' they face.

The lack of understanding of barriers to entry is also present in the reasoned opinion of the Polish Sejm. They chastise the Commission for failing to present any analysis which would help identify the causes of the underrepresentation of women. The Sejm suggests that 'comparing the number of women who have applied for the highest company positions in the individual Member States vs. the number of those who were finally appointed would be a more reliable method in this respect'. Sadly, for the reasons mentioned above, that is clearly not the case. Women do not apply even when equally or better qualified than men, and if discrimination is wide-spread enough, women will be smart enough not to engage in an application exercise they will know is futile. This is quite aside from the fact that many positions on boards (both executive and non-executive) are not filled through an application process, but often through invitations, based on informal networks which tend to be male.

The question of criteria for selection brings with it the question of merit. The objecting domestic chambers assume that the current set-up is actually based on merit

\footnotetext{
$<$ https:// www.newyorker.com/ science/ maria-konnikova/ lean-out-the-dangers-for-women-whonegotiate> accessed 11 November 2018.

35 Mohr (see note 33).

36 ibid.

37 ibid.
} 
and/or that the definition of merit is gender-neutral. In the words of the Czech Chamber of Deputies:

A general objection of the critics of positive measure especially in the form of quotas (sic!) in companies, is the negation of the principle of meritocracy as the fundamental criterion for the selection of the best candidates for executive supervisory ('exekutivní dozorč́' ${ }^{38}$ ) position. 39

This shows an unawareness of a cultural environment which has long defined merit based on typically male qualities, and, in turn, fostered male qualities which fulfilled this understanding of merit. There is no acknowledgement of the existence of gender stereotypes and bias, which leads to the overlooking of qualified women as well as to overlooking different qualifications connected more often to women's rather than men's careers. ${ }^{40}$ One way of understanding these numerical targets is to see them as measures reversing a pre-existing pro-male bias, rather than creating an 'artificial' pro-female one. This eludes the Czech Deputies. And they are not alone - a similar position was presented by the Romanian Chamber of Deputies, which stated that board members should be 'determined by professional competency, regardless of gender, ${ }^{\prime} 41$ as well as by the Estonian Parliament, which stated:

[C]ompulsory quotas might create a situation where women are elected into leadership teams of companies to fill a quota and not on the strength of their abilities or prior achievements. 42

This merit-optimism is propped up by a belief in the gender-neutrality of the markets and a belief that business decision-making is always rational. The Czech Chamber of Deputies stated:

Private companies, because they are exposed to competition in the market, reduce the criteria for candidates to such intellectual and personal characteristics, which will enable them to best succeed on the market. Other

\footnotetext{
38 The text, somewhat confusingly, uses both the word exekutivní (which is more apt for executive boards) and dozorč́ (which is the name for non-executive boards).

39 Czech Chamber of Deputies, 7.

${ }^{40}$ Managerial experience in the governmental or non-governmental sector, over for-profit, might be an example.

${ }^{41}$ I thank Elena Brodeala for the translation of this text from Romanian.

42 Estonian Parliament.
} 
criteria bring the risk of the lowering of the professional standard, which lowers the competitive ability of a company. 43

Again, this is an unduly optimistic perspective, which ignores the fact that some employers are willing to pay more and take efficiency hits just to be able to discriminate. 44

\section{The solution and the underlying understanding of equality}

As for the solution, some objections were based on a misunderstanding of the nature of the measure. The Czech Chamber of Deputies called it a 'quota'. 45 The Estonian Parliament too, called it a 'compulsory quota' and stated that '[u]nfair treatment should not be combated with discriminatory measures, however temporary in scope.'46

Both labels are incorrect. First, as for 'quota', theOED defines it as 'a fixed share of something that a person or group is entitled to receive or is bound to contribute'. ${ }^{47}$ The legal understanding of that term varies somewhat by jurisdiction, but it is commonly understood as preferential treatment of candidates from underrepresented groups even when they are less qualified. ${ }^{48}$ In this sense, the numerical expression of the aim of $40 \%$ suggests a quota, but all the other characteristics of the Proposal distinguish it: the provisions of the Proposal follow the CJ EU's requirement of equal qualifications of candidates, thus not allowing just any candidate to fill the numbers; and the 'quota' is not mandatory, since the Proposal does not set up a clear sanction mechanism.

\footnotetext{
${ }^{43}$ Czech Chamber of Deputies, 7.

${ }^{44}$ The 'taste-based' economic model of labour market discrimination, first introduced by Gary Becker, suggests that employers are willing to pay a financial penalty to discriminate. Becker himself, however, believed that markets can eventually eliminate these distortions to create an equilibrium. Newer research shows that this only partially explains inequalities in the labour market, but confirms that markets can operate without eliminating irrational discriminatory practices. International Encyclopedia of the Social Sciences, 'Discrimination, Taste For' <https:// www.encyclopedia.com/ social-sciences/ applied-and-social-sciencesmagazines/ discrimination-taste> accessed 11 November 2018.

45 Czech Chamber of Deputies, 7.

46 Estonian Parliament.

47 Oxford Living Dictionaries, 'Quota' <https:// en.oxforddictionaries.com/definition/ quota> accessed 11 November 2018.

48 McCrudden (see note 27) 164-5.
} 
It is worth noting that the Proposal does push the envelope on 'mandatory' in one sense. Positive action under Art 157(4) TFEU is not obligatory. ${ }^{49}$ While it allows MSs to adopt positive measures, it certainly does not require or even encourage them. This means that in some MSs, positive action is domestically not allowed. In Slovakia, for example, the Constitutional Court in $2005^{50}$ invalidated a provision of the Antidiscrimination Act on the basis of it being incompatible with the Slovak Constitution's equality provision. ${ }^{51}$ Under EU law, this is a possible outcome. The fact that the Proposal does require MSs to come up with programmes to reach the stated target, introduces, for the first time, an EU requirement to positively act to promote greater equality and a particular result. This aspect clearly causes particular discomfort in some post-socialist Central and Eastern European states and is likely at the root of the label 'quota' for the measure.

Second, the accusation of discrimination is also wrong, because of the already mentioned requirement of equal qualifications of candidates. Moreover, the Proposal is a symmetrical measure - it speaks about the 'under-represented sex' rather than about representation of women. This is in line with the Treaty provision on positive action, Art 157(4) TFEU:

With a view to ensuring full equality in practice between men and women in working life, the principle of equal treatment shall not prevent any Member State from maintaining or adopting measures providing for specific advantages in order to make it easier for the underrepresented sex to pursue a vocational activity or to prevent or compensate for disadvantages in professional careers.

The Treaty-makers, as well as the Commission, thus combined an asymmetrical with a symmetrical approach to equality. They accepted the need for asymmetric

\footnotetext{
49 Nor were/ are the provisions of the other equality directives.

50 Decision of the Constitutional Court of the Slovak Republic of 18 October 2005, Ref No Pl.ÚS 8/ 04202, published as No 539/2005 Coll. For a discussion, see Barbara Havelková, 'Burden of Proof and Positive Action in Decisions of the Czech and the Slovak Constitutional Courts - Milestones or MillStones for Implementation of EC Equality Law?' (2007) 32 European Law Review 686.

51 Slovakia is not the only country where the compatibility of positive action was challenged as incompatible with the constitutional principle of equality. The French Constitution needed to be amended for that purpose and in Germany, concerns were raised about the compatibility of quota with not just the right to equality, but the right to property and freedom of association. See Senden (see note 19) 85 , and the references therein.
} 
measures to combat inequality, but then pretended this inequality falls symmetrically on both sexes. This is, to my mind, unfortunate, since we do care about the criterion of sex ${ }^{52}$ because it creates asymmetry not randomly, case-by-case, but it systematically hierarchizes the male over the female. Sex is an axis of disadvantage in society which negatively affects women more than men, especially when it comes to access to power and decision-making. Not so long ago, in many European countries, this disadvantage was explicitly enshrined in the law (eg depriving women of property rights or suffrage, or limiting their access to certain employment, divorce, etc) and today continues to be socially and culturally, if no longer legally, pervasive. To put this bluntly, we are suspicious of the criterion of sex because of howit has disadvantaged women, not men. By speaking about under-represented sex, both the Treaty and the Proposal explicitly preclude situations where the criterion of sex is directly or indirectly 53 used to compensate this disadvantage (eg women-only workplaces or companies). Moreover, this attempt at even-handedness did not persuade the sceptical MSs about the acceptability of the measure.

I have argued elsewhere that post-socialist MSs have never truly experienced a bottom-up debate about why anti-discrimination law was needed. When their parliaments adopted anti-discrimination legislation, it was to fulfil EU membership obligations, not because they subscribed to its aims or even its understanding of what discrimination is and how it comes about. 54 And while the EU anti-discrimination acquis was - reluctantly - transposed, it is far from being effectively implemented. ${ }^{55}$ Moreover, the more substantive or asymmetrical a measure, the less it is typically accepted. Because some post-socialist MSs' political representation and judges tend to be sceptical or dismissive of the pervasive asymmetry of social reality, they would tend not to accept asymmetrical solutions to address it. One example of this was the Slovak

\footnotetext{
52 Using the concept of gender - and promoting the fight against gender stereotypes - could get rid of the problem of choosing one sex as addressee or pretending both are equally disadvantaged. But that is not the current state of the text.

53 By 'indirect' I mean a situation where the predominance of women is not the consequence of using the criterion of sex directly, but it is a result of application of other criteria or even self-selection. While the direct use of sex would be precluded in all situations, its indirect use - where there are in effect more or only women - can be justified. The latter has been termed 'indirect affirmativeaction', see eg Daniel Sabbagh, The Rise of Indirect Affirmative Action. Converging Strategies for Promoting "Diversity" in Selective Institutions of Higher Education in the United States and France' (2011) 63 World Politics 470,472 .

54 I detail this on the example of the Czech Republic in Havelková, Gender Equality (see note 11) 225238.

55 ibid, 243-67.
} 
Constitutional Court ruling on positive action. ${ }^{56}$ Another was a challenge brought by an ordinary court to the Czech Constitutional Court, where the provision on the shift of burden of proof from plaintiffs to defendants in anti-discrimination cases was argued to be incompatible with the constitutional requirement of procedural equality of the parties. ${ }^{57}$ The objections to the Proposal are rooted in this formal understanding of equality which only permits equal treatment - equality means symmetry - and under which any positive measures are discriminatory.

These objections show that the Commission might have underestimated the different views on the social reality of inequality and anti-discrimination law prevalent in some of the old and new MSs. It did not seem to realize that the Proposal needed two different conversations: one focused primarily on corporate governance with the old Member States, and one examining and where necessary enlightening on gender equality with the new ones. My previous research ${ }^{58}$ and my observations above show that some of the new MSs might be very resistant to these arguments. Without them, however, substantive equality measures will continue to face fierce opposition.

It is also clear that at least some of the new MSs' objections pose a fundamental challenge to the 'common value' and central aim of equality between men and women, as stated in Art 2 and 3 TEU. In particular, they pose a challenge to a more substantive understanding of equality, apparent in concepts such as indirect discrimination, shift of burden of proof or positive action, the latter of which has arguably been evolving

\footnotetext{
56 See $n$ 50; for a discussion, see ibid, 268-71.

57 CCC Decision of 26 April 2006, Ref No Pl.ÚS 37/04, published as No 419/2006 Coll. Unlike in the Slovak case, the provision was not invalidated. I have argued elsewhere, that this was more for reasons of the binding nature of the relevant EU directive rather than because of a more substantive understanding of equality. See Barbara Havelková, 'Burden of Proof and Positive Action' (2007) (see note 50).

58 I have shown elsewhere that gender equality law in Czechia faces serious intellectual and conceptual difficulties, which are at least partly path-dependent on state socialism. These include an essentialist understanding of the differences between men and women (which socialist states never challenged), a notion that equality and anti-discrimination law is incompatible with freedom (a strong, absolutist neoliberal narrative of freedom having emerged in reaction to state socialism), and a perception that existing laws are objective and neutral, while any new gender-progressive regulation of social relations is an interference with the 'natural social order' (a critical, constructivist, post-structuralist paradigmatic turn not having happened in social sciences in the region) and an unacceptable 'social engineering' (transformative use of lawbeing rejected as 'communist'). See Havelková, Gender Equality (see note 11).
} 
through the case-law of the CJ EU as well as through the secondary legislation, and the Treaty itself. 59

So what if some of the new MSs are actually challenging the Commission's interpretation of what aims and subsequently what types of measure are permissible at EU level? Is this a question of allocation of power between the EU and MSs and can it be understood in terms of subsidiarity?

C. Is a disagreement about the aims which can be pursued part of a subsidiarity assessment?

Daniel Halberstam distinguishes between 'substantive subsidiarity' and 'instrumental subsidiarity'. ${ }^{60}$ Substantive subsidiarity, 'seeks to determine which level of governance is best suited to determine whether a particular objective should be considered a policy goal at all'. ${ }^{61}$ Answering the question, 'involves a morally and politically complex assessment of relative substantive claims of authority'.62 Once this authority is established, one asks the instrumental question - who is going to be better suited to achieve a given goal. This 'involves a technically complex empirical investigation into the relative capacities and incentives of the various levels of government in tackling a given problem.'63 For Halberstam, Art 5(3) TFEU only addresses the instrumental question: 'the provision presupposes that the central government has the authority to determine "the objectives of the proposed action" and then asks who can best achieve the centrally specified goal of governance.'64

This would mean that any 'substantive' questions are extraneous to subsidiarity in the sense of the EU Treaties. Does that mean they are outside any contestation? One could argue that this objection is really about 'legal basis' - if the EU interpreted the

\footnotetext{
${ }^{59}$ Aside from Art 157(4) TFEU, positive action has also been recognized in Art 23(2) of the Charter.

60 Daniel Halberstam, 'Comparative Federalism and the Role of the J udiciary' in Gregory A Caldeira, R Daniel Kelemen and Keith E Whittington (eds), The Oxford Handbook of Law and Politics (Oxford University Press 2008) 153. See also Irene Wieczorek who identifies three criteria for the allocation of power: performance, normative and political values: Irene Wieczorek, The Principle of Subsidiarity in EU Criminal Law' in Chloé Brière and Anne Weyembergh (eds), The Needed Balances in EU Criminal Law. Past, Present and Future (Hart Publishing 2017).

61 Halberstam (see note 60) 154.

62 ibid 154.

63 ibid 154. This is supported by the examination of the travaux preparatoires, carried out by Irene Wieczorek. She notes that the subsidiarity principle has always been understood as a 'comparative efficiency test'. Wieczorek, 'The Principle of Subsidiarity in EU Criminal Law' (2017) (see note 60) 79. 64 Halberstam (see note 60) 154.
} 
EU aim wrongly, then they should not have acted at all for lack of competence. I mentioned above that despite the textually narrow focus of the EU's Early Warning System ('EWS') on subsidiarity, it has become accepted practice to have a wider conversation on EU legislative proposals between the national parliaments and the Commission. The issue of how to understand the EU's aims can be and has been raised by the MSs (de facto, if not strictly speaking legally correctly).

Whether or not the new MSs are right in their challenge in this instance is another matter, however. Considering the fact that when joining the EU in 2004, they were signing up to well-developed system of sex equality law, it should not be coming as such a surprise now that it is overall a substantive understanding of equality which the EU subscribes to. 65

\section{RIGHT TO OWNERSHIP AND FREEDOM OF ENTERPRISE}

Before looking at conferral, subsidiarity and proportionality, it ought to be mentioned that several national parliaments raised another set of more policy-based objections, having to do mainly with private enterprise and business freedom. Even here, there was some difference between old and new MSs. Comments coming from post-socialist countries seemed to take as understood that there is an inevitable clash between the aim of gender equality on one hand and entrepreneurial freedom and private ownership on the other. The Czech Senate emphasised the clash with ownership rights: 'in essence, [the proposed measure] limits the exercise of ownership rights by shareholders in their decision-making regarding the composition of senior management of companies which they own'.66 For this reason, the Czech Senate felt the private sector should not fall under legal obligations relating to gender equality:

the efforts for a political solution of the issue of gender imbalance should primarily focus on the question of equal representation in political

\footnotetext{
65 It is perhaps worth adding that since this is an area of shared competence, the concrete aims of the EU and the MSs can be different. Beyond what the EU requires, the objecting MSs can pursue their own understanding of gender equality. But having that different domestic understanding does not negate or undermine the EU's own.

66 Czech Senate.
} 
institutions, public authorities, public law bodies and publicly-owned companies.

Similarly, following its comments which conceptualized the measure as unacceptable discrimination, the Estonian Parliament observed that they are even less justified if the planned measures have the potential of restricting business freedom or if they ignore the functioning logic of the business environment.' These comments show that, rather than objecting to the adoption of the measure at EU level only, new MSs are more fundamentally opposed to value-based regulation in this area.

It is here worth reminding ourselves that the ECJ has made clear that the freedom to choose an occupation and the freedom to conduct a business

like the right to property, is not an absolute right but must be considered in relation to its social function [...] Consequently, restrictions may be imposed on the exercise of those freedoms, provided that those restrictions in fact correspond to objectives of general interest pursued by the European Union and do not constitute, with regard to the aim pursued, a disproportionate and intolerable interference, impairing the very substance of those rights. 67

The objections of the national parliaments do not seem to acknowledge the limited nature of the right or weigh it against other values.

Both the French Senate and the Swedish Riksdag also expressed concerns. Both related more concretely to specifics of the Proposal rather than putting gender equality in opposition to other rights in general. The French Senate was sceptical about the rules addressing the process of appointment, 68 which they saw as intruding into the organization of private companies and being contrary to the constitutional principles of entrepreneurial freedom ${ }^{69}$ (la liberté d'entreprendre). The Riksdag expressed a concern about limiting the rights of owners to choose their managers and company supervisors.

${ }^{67}$ C-544/ 10 Deutsches Weintor v Land Rheinland-Pfalz ECLI:EU:C:2012:526 (6 September 2012) para 54, emphasis mine. See also C-134/ 15 Lidl v Freistaat Sachsen ECLI:EU:C:2016:498 (30 J une 2016), relating to the protection of health and consumer protection respectively.

68 Art $4(1,3,4,5)$

${ }^{69}$ Author's translation. 


\section{LEGAL BASIS}

The Commission used Art 157(3) TFEU as the legal basis for the Proposal. The provision stipulates that ordinary legislative procedure can be used to 'adopt measures to ensure the application of the principle of equal opportunities and equal treatment of men and women in matters of employment and occupation'. 70 This competence, as well as the wider competence in Art 19 TFEU which allows the EU to counteract discrimination beyond the ground of sex and beyond employment and occupation, were added by the Amsterdam Treaty. Before then, EU action was based either on the internal market provision (today Art 114 or 115 TFEU) ${ }^{71}$ or the 'residual' powers provision (now Art 532 TFEU). ${ }^{72}$ As I mentioned already, in justifying the measure, the Commission focused very much on internal market rationales, concentrating on cross-border impact. This might be an overhang from the past, but was certainly no longer necessary given the new legal basis. ${ }^{73}$

The legal basis of the Proposal was questioned by two national parliaments only: the Czech Chamber of Deputies and the Polish Sejm. Both chambers expressed doubts that Art 157(3) was the correct legal basis considering its scope is limited to 'employment and occupation'. The Polish Sejm tied Art 157(3) to the term 'worker' employed in Art 157(1), pointing out that holding the supervisory position in a joint stock company is not always tantamount to employment (within the meaning of TFEU)...In some cases the direction or even the remuneration component is missing.' This, however, ignores both the fact that 'worker' is not mentioned in paragraph 3 , and that the provision moreover explicitly goes beyond employment by speaking of 'occupation'. As Linda Senden persuasively pointed out:

[E]quating 'occupation' with 'employment'... would entail that 'occupation' would be devoid of any proper meaning...A more logical interpretation would be that its added value lies precisely in covering those situations of

\footnotetext{
70 Emphasis mine.

${ }^{71}$ For example the first ever Council Directive 75/117/EEC on the approximation of the laws of the Member States relating to the application of the principle of equal pay for men and women [1975] OJ L045/ 19 was based on then Art 100 EEC, now Art 115 TFEU.

${ }^{72}$ Eg Council Directive 76/207/EEC on the implementation of the principle of equal treatment for men and women as regards access to employment, vocational training and promotion, and working conditions [1976] OJ L039/40.

${ }^{73}$ See, similarly, Senden (see note 19) 88.
} 
professional activity that are not captured by the notions of (self)employment.., including also the professional activity of non-executive board membership. ${ }^{74}$

One might wonder why the Commission did not use the much wider competence provided for in Art 19 TFEU. The only limitation there is that the action be taken 'within the limits of the powers conferred... upon the Union'. The answer is probably quite pragmatic: while Art 157 only requires qualified majority in theCouncil, Art 19 requires unanimity.

One could perhaps speculate that there might have been advantages to the use of Art 19. First, a greater consistency could have been achieved between the actual aim of the measure and the legal basis. Arguably, the Proposal was put forward primarily to achieve greater gender equality in economic decision-making, rather than improve occupational opportunities of relatively few women at the top. ${ }^{75}$ Second, one could ask whether the restrictive case-law on the CJ EU on positive action, developed in the area of employment, would apply if the measure was adopted with a non-employment justification. On the other hand, while Art 157(3) speaks of 'equal opportunities', Art 19 foresees 'action to combat discrimination'. And although it is not impossible to justify positive action as a measure that combats discrimination, it would require some added elaboration.

An interesting challenge to the use of Art 157(3) was raised by the Czech Chamber of Deputies. The MPs suggested that Art 157(4) which explicitly allows for positive action at the MSs level is lex specialis to the preceding paragraph. This would lead to the conclusion that positive action was meant to be left to the MSs. But since the fourth paragraph is formulated in enabling terms (vis-à-vis MSs) rather than restrictive terms (vis-à-vis the Union), and there is nothing in Art 157(3) to indicate positive action is excluded, this argument appears invalid.

\footnotetext{
74 ibid 90. Moreover, as she points out, and as the Commission noted in its response to the Polish Sejm, the CJEU has not excluded the possibility that board members might be 'workers'. See C-232/09 Danosa $v$ LKB Lizings SIA ECLI:EU:C:2010:674 (11 November 2010).

75 See also Suk (see note 7) 7. This would require finding an anchor competence elsewhere in the Treaty. The EU is active in the area of corporate governance, mainly in order to facilitate freedom of establishment (see esp Art 50(2) TFEU). It is worth noting that this might not mean the reintroduction of internal market logic into the Proposal, since the question of 'scope' of competence and the subsequent use of Art 19 TFEU are separate.
} 
A related point, not raised by the national parliaments but identified by Lisa Senden, 76 is that 'equality of opportunity', mentioned in Art 157(3), is different from 'equality of results'. She herself rebuts this point with two observations. First, the numerical target in the Proposal is 'aspirational' - the measure sets an 'obligation of effort'77 rather than one of result. Second, as was also discussed in section I.b above, positive action, especially of the 'tie-break' type, can be seen as merely neutralising existing barriers. Given what we know about male-centred understandings of merit and gender biases, setting a target for getting more women is one way in which equal opportunity is finally fostered where it previously would not have existed.

\section{PROPORTIONALITY}

The question of proportionality was raised rarely and not very persuasively. These objections were not only fewer, but also arguably more easily dealt with. I therefore discuss them now, despite the fact that the question of proportionality typically follows the one on subsidiarity, both in the wording of the Treaty and in judicial decisionmaking.

The strongest point relating to proportionality was a challenge to using hard law. The Czech Chamber of Deputies and Senate raised the point that the Commission should have tried soft-law measures first. The response to this point is reasonably at hand: Linda Senden notes that the EU has already pursued a soft law course of action for the past 30 years,' without noticeable results. ${ }^{78}$

Other proportionality challenges were pre-empted by the limited scope of the Proposal and by leaving much of the detail, including sanctions, to the MS (as discussed in section I.a above). Moreover, the Commission did quite a thorough job of assessing possible alternatives. The Explanatory Memorandum presented five possible options: 1) no action, 2) Recommendation, 3) Directive on non-executive boards, 4) Directive also containing flexible objectives for executive boards, 5) Directive setting a binding objective for both non-executive as well as executive

\footnotetext{
76 Senden (see note 19) 89-90.

77 ibid 90.

78 ibid 92 and the references therein.
} 
boards. Since the Commission chose the middle option, and the mildest of the hardlaw alternatives, it was hard to argue that the action was disproportionate.

So mild was the choice that the Czech Senate noted that since the Proposal only concerned non-executive boards, this 'significantly limit[ed] its real impact on equal opportunities for women and men, and raise[d] doubts about the effectiveness and meaningfulness of this proposal with regard to its intended objective'. This is an interesting observation which indicates a clash within proportionality. Namely, choosing the absolutely least intrusive option to fulfil the criterion of necessity can compromise suitability - a measure might be so mild as to no longer be suitable. ${ }^{79}$ The claim of lack of suitability is, however, weak. While some of the benefits of the Proposal as presented by the Commission (especially in relation to economic performance of companies) are somewhat controversial, as I discuss below, the fact that the measure would directly increase the percentage of women on non-executive boards, as well as indirectly benefit career development of women at lower levels of an organization, has not been seriously put in doubt.

\section{SUBSIDIARITY}

The principle of subsidiarity states that:

[T]he Union shall act only if and in so far as the objectives of the proposed action cannot be sufficiently achieved by the Member States, either at central level or at regional and local level, but can rather, by reason of the scale or effects of the proposed action, be better achieved at Union level. 80

Several member states noted that neither the requirement that the objectives 'cannot be sufficiently achieved by the MSs' nor the requirement that they be 'better

\footnotetext{
79 This is a known problem for anti-discrimination law: in order to only do what is necessary, or to 'narrowly tailor' in the terminology of the US, institutions minimize the use of a protected characteristic. This can also minimize the effects of the measure, which can then lead to the measure being considered ineffective and thus unjustified. Discussing the US desegregation case Parents Involved in Community Schools v Seattle School District No 1, 551 US 701 (2007), especially J ustice Robert's speech, Sumi Cho noted that this constitutes a catch-22, 'where a narrowly tailored remedy is invalidated because compliance thereto will almost always fail to be the most effective remedy, while a failure to narrowly tailor is always invalidated.' Sumi Cho, 'Post-Racialism' (2009) 94 Iowa Law Review 1589, 1619. I thank Mathias Möschel for a helpful discussion on this topic.

80 Art 5(3) TEU.
} 
achieved at Union level' were fulfilled. The lack of evidence for these, as well as for the business case for numerical targets, were a red thread running through the objections. The UK House of Commons noted that not only were the two substantive conditions not fulfilled, but that due to lack of evidence, the Commission failed the procedural requirement to substantiate - it did not fulfil its 'duty to give reasons'. ${ }^{81}$

In the following, I look at the Commission's use of economic rationales to justify the measure in general (section V.a), and the use of the 'internal market logic' to justify subsidiarity more specifically. I discuss the question of sufficiency of MS-level action (section V.b) and the better ability of the EU to achieve the aims of the proposed action (section V.c).

\section{A. The economic rationale}

Three possible rationales can be identified for positive measures to increase the presence of women on company boards. ${ }^{82}$ The first is economic. It takes the perspective of the enterprise or the economy as a whole and views positive measures instrumentally. There are, however, also value-based, principled reasons. The second possible rationale focuses on democracy. The third on individual rights, both from a perspective of gender equality.

81 [W] do not consider that the Commission has provided sufficient qualitative and quantitative substantiation of thenecessity for action at EU level, given that a number of Member States havealready taken measures to increase the presence of women on corporate boards. This omission, the House of Commons submits, is a failure on behalf of the Commission to comply with essential procedural requirements in Article 5 of Protocol (No 2).'

82 I am, of course, not the first person to classify the normative aims underlying either positive action more generally, or measures targeting gender inequality on company boards specifically. For the former, positive action more generally, Chris McCrudden identified six aims used in different jurisdictions: 1) helping to prevent current discrimination and stereotyping, 2) compensation for past discrimination, 3) egalitarian/redistributive argument, 4) identity and recognition, 5) diversity, 6) social cohesion. McCrudden (see note 27) 166-9. Linda Senden and Goran Selanec, drawing on reports by EU Member States, identify three goals of positive measures at domestic level: 1) to improve the ability of the disadvantaged group to compete for the available opportunities, 2) to limit the negative effects on women's position in the labour market of the unequal distribution of responsibilities in the family, 3) to ensure the balanced representation of men and women in bodies with significant decisionmaking powers. Goran Selanec and Linda Senden, Positive Action Measures to Ensure Full Equality in Practice between Men and Women, including on Company Boards (European Commission, 2011), 67. For the latter, the Proposal itself, three aims are typically identified: 1) a business case, 2) a democratic rationale, and 3) an individual human rights rationale. See eg Senden (see note 19) 83. 
The Commission based its Proposal mainly on the first of these aims, which I discuss and critique below. In terms of the second and third possible rationales democracy and human rights arguments - over the years of existence of the EEC/EU there has arguably been a shift from economic rationales to these value-based justifications. This has been the case for EU equality law more generally, 83 as well as specifically for the Proposal. This shift has tended to be welcomed by scholars of equality law. 84

As far as the principle of democracy is concerned, $85 \mathrm{~J}$ ulie Suk has noted that in the process of adoption of the Proposal, it was the European Parliament's amendments which shifted the orientation from economic advantages to a 'comprehensive vision of gender equality'. ${ }^{6}$ Most importantly, she notes the added language of 'democratic deficit'87 in relation to participation and representation of women in decision-making. As for individual rights, the fundamental right of 'equality between women and men...,

\footnotetext{
83 On a shift to democracy, see Ruth Rubio-Marin, 'A New European Parity-Democracy Sex Equality Model and Why it Won't Fly in the United States' (2012) 60 The American Journal of Comparative Law 99. As for a shift from an economic to social to fundamental-rights understanding, the story is well-known. Equality and anti-discrimination law began with market-making aims, with the original requirement of equal pay being introduced to level the playing field for France, which already had such a provision, as documented and discussed in Catherine Barnard, The Economic Objectives of Article 119' in Tamara Hervey and David O'Keeffe (eds), Sex Equality Law in the European Union (Wiley 1996) 321-334; Gillian More, 'The Principle of Equal Treatment: from Market Unifier to Fundamental Right' in Paul Craig and Grainne de Burca (eds), The Evolution of EU Law (OUP 1999). The social aims of the provision were recognized in the mid-1970s by the Court in C-43/ 75 Defrenne v Société anonymebelge de navigation aérienne Sabena (Defrenne II) ECR [1976] 455. Two decades later they were unambiguously identified as primary in C-50/ 96 DeutscheTelekom AG v Schröder [2000] ECR I-0074, para 57. The right to equality and non-discrimination has also been recognized as a fundamental right, both judicially in C-149/ 77 Defrenne III [1978] ECR 1365 para 26 and at the constitutional/Treaty level through the adoption of Art 20, 21 and 23 of the Charter of Fundamental Rights of the European Union.

84 Eg Ruth Rubio-Marin, looking at the EU and the domestic level of MSs, shows and commends the shift from a narrower anti-discrimination law frame of sex/gender equality to one focusing on disempowerment - the 'parity democracy sex equality model'. Ruth Rubio-Marin, 'A New European Parity-Democracy' (2012) 60 The American J ournal of Comparative Law 99.
}

85 Art 2 TEU, among others. Arguably, another EU fundamental value which could be used to normatively underpin the Directive, was 'social market economy', Art 3(3) TEU. Marek Szydlo makes this point, emphasising in particular that it is democratic governance and stakeholder participation in corporate decision-making which could be emphasised under this rubric. Szydlo (see note 19) 181-4.

86 Suk (see note 7) 5.

${ }^{87}$ Recital 10. Suk interestingly notes that the greater democratic legitimacy of big European corporation would indirectly promote greater democratic legitimacy of the EU itself, because of their involvement as social partners in EU's own decision-making, (see note 7) 5-8. 
one of the Union's founding values and core aims' 88 is recognized as underpinning the Proposal in the first sentence of the first recital of the Preamble. 89

Nonetheless, it was the economic rationale which was emphasised most strongly by far. In the Preamble to the Proposal, the Commission stated that 'gender equality policies are vital to economic growth, prosperity and competitiveness'. It then presented three main economic advantages: ${ }^{90}$ 1) greater efficiency in the use of human resources: 'make full use of all available talent, knowledge and ideas, thus enriching diversity of human resources and improving business prospects';91 2) improve corporate governance, because team performance and the quality of decision-making are enhanced due to a more diverse and collective mind-set'; 92 and 3) 'financial performance and profitability'. 93

There are several issues with the economic rationale. Because it relies on instrumentality, should the results not pan out, the whole project can be normatively undermined. ${ }^{94}$ This is particularly troubling in a situation where the research on the benefits for companies is inconclusive. ${ }^{95}$ Indeed, research suggests that most regimes will have a combination of positive and negative ${ }^{96}$ outcomes, depending on the particular national regulation and context, as well as the criterion used to assess outcomes. Nina Smith's meta-report identified several positives of company board 'quota':

\footnotetext{
${ }_{88}$ Citing Article 2 and Article 3(3) of the Treaty on European Union.

${ }^{89}$ Considering the Commission then spent at least twelve recitals on documenting economic arguments (Recitals 4-16), the fundamental rights sections of the Preamble can feel somewhat anaemic by comparison.

90 This typology is also identified in Szydlo (see note 19) 173-175.

${ }^{91}$ Recital 5. From 'knowledge' onwards, the text was added by the EP. See also Recital 7.

92 Recital 8.

93 Recital 8. See also Recital 9.

${ }^{94}$ For a similar point, in the US context and in relation to race, see Lisa M Fairfax, "The Bottom Line on Board Diversity: A Cost-Benefit Analysis of the Business Rationales for Diversity on Corporate Boards' [2005] Wisconsin Law Review 795.

95 This was noted by several national parliaments, most comprehensively by the House of Lords. European Union Committee, 'Women on Boards' (see note 13).

${ }^{96}$ Some research has shown that quota might have not just negative results, but possible unintended other negativeeffects. Monika Leszczynska offered a survey of experimental social-psychology literature which indicates that quota can have both, negative effect on perception by colleagues, as well as selfperception of female beneficiaries. Monika Leszczynska, 'Mandatory Quotas for Women on Boards of Directors in the European Union: Harmful to or Good for Company Performance?' (2017) 19 European Business Organization Law Review 35, 44.
} 
1) Quotas increase the number of women on boards of directors; 2) The decision-making process improves with greater gender diversity on boards, 3) Having female board members seems to improve board attendance, 4) Having female top executives may have positive effects on the career development of women at lower levels of an organization; and 5) Boards with more female members tend to be tougher monitors of company executives. ${ }^{97}$

She also identified negatives:

1) Boards with diverse members or members who differ from the company's senior management may experience communication problems internally and with management; 2) Quotas imply that less experienced women will join boards because the supply of qualified women in senior executive positions is thin [this would not apply to the EU's Proposal, as equal qualification is required]; 3) Quotas seem to have little positive effect on increasing the pool of women with senior executive experience; 4) Despite some positive outcomes, the short-term performance effects of female board members are insignificant or negative, and it is too soon to establish the long-term effects. 98

Similarly, in a more US-centred meta-study, Deborah Rhode and Amanda Packel conclude that while the relationship between diversity and financial performance has not been convincingly established', there is 'some theoretical and empirical basis for believing that when diversity is well managed, it can improve decision making and can enhance a corporation's public image by conveying commitments to equal opportunity and inclusion'.99 On Norway, the trail-blazing country which first adopted legal quota in 2003, J ulie Suk summarizes, there is both: a) 'research showing that the speed of change led to an "'exogenous shock", which had a substantially negative impact on the value of these firms' and that the quota led 'to increased labour costs and reduced short-term profits in the affected firms', as well as

\footnotetext{
${ }^{97}$ Nina Smith, 'Gender Quotas on Boards of Directors. Little Evidence that Gender Quotas for Women on Boards of Directors Improve Firm Performance' (May 2014) $<$ https:// wol.iza.org/ uploads/articles/ 7/ pdfs/ gender-quotas-on-boards-of-directors.pdf?v=1> accessed 25 May 2018, 1.

98 ibid 1.

99 Deborah Rhode and Amanda Packel, 'Diversity on Corporate Boards: How much Difference does Difference Make?' (2014-2015) 39 Delaware J ournal of Corporate Law 377, 377.
} 
b) research suggesting 'that having a critical mass of women on boards enhances the level of firm innovation'. ${ }^{100}$ In an interview-based study of the French quota, Darren Rosenblum and Daria Roithmayer found indications that 'adding women to a board may well have a substantive impact on decision making, not because of the sex of newly added member but because they are more likely to be outsiders... more likely to be foreign, to be expert in a wider range of areas, and to be drawn from non-elite networks than their male counterparts'. ${ }^{101}$

To summarize, while there might be benefits in relation to reputation, governance, or board decision-making, it has been disputed that increasing women's representation improves corporate financial performance. 102 And the 'success'103 might depend on the details of the domestic regulation (eg soft vs hard quota or size of companies to which it applies), existing corporate structures, as well wider context (both material, such as existing levels of participation of women in the workforce and management more specifically, as well as cultural, such as the understanding and support of gender equality).

Given the inconclusiveness of the evidence, the quality and neutrality of the Commission's Impact Assessment and its presentation of the evidence has been questioned and criticised by academics. 104 And it has been noted and denounced by national parliaments. 105 The national parliaments' complaint of insufficient evidentiary basis for the Proposal was a strong and recurrent one. While it mainly focused on the question of the (in)ability of MSs to achieve progress, and the benefits on EU-level action, the fact that the Commission's credibility on evidence on targets for company boards per se was weakened from the get-go certainly did not help matters.

\footnotetext{
100 Suk (see note 7) 3, and references therein.

${ }_{101}$ Darren Rosenblum and Daria Roithmayer, 'More than a Woman: Insights into Corporate Governance after the French Sex Quota' (2015) 48 Indiana Law Review 889, 889.

102 These four different criteria were put forward by Rhode and Packel (see note 99).

103 The definition of 'success' itself can vary by country and by research question of the individual studies.

104 Leszczynska (see note 96). For a sceptical view of the Commission's aims, see also Szydlo (see note 19).

105 Notably in the House of Lords. European Union Committee, 'Women on Boards' (see note 13). This report was not part of the House of Commons' submission under the Subsidiarity Protocol, but the overall findings were reiterated in its reasoned opinion.
} 
The emphasis the Commission put on the economic rationale has not been unique to the Proposal and the question of women in economic decision-making. The EU has seen violence against women very much in economic terms too. For example the abstract of a recent European Parliament report mentions the EU-wide cost of violence against women in its third sentence. ${ }^{106}$ Above I noted an increased emphasis on value-based understanding of gender equality, apparent in the text of the Treaty and judicial decision-making. In relation to the Commission and the Council in particular, however, Anna Elomäki has observed that a market-oriented gender equality discourse has escalated in recent years and the shift from a rights-based to the market-oriented economic case has been intentional on the part of these institutions. 107 She notes that the 'stated goal behind developing the economic case was to sell gender equality to decision-makers with persuasive arguments about costs and benefits' has not been achieved, however. ${ }^{108}$ My analysis of this Proposal confirms her observations.

\section{B. Can the objectives be achieved by MSs?}

The argument that the Commission failed to prove that 'the objectives of the proposed action cannot be sufficiently achieved by the Member States' came in particular from MSs which themselves have taken some action towards redressing the imbalance of gender representation. This is both surprising and unsurprising. It is surprising, since one would expect that these states would be the closest to fulfilling the eventual Directive's provisions. This would be the case had they chosen similar rules and criteria. However, several MSs, such as Sweden and the UK, as well as eventually Denmark, 109 chose a business-led model of self-regulation. And several others chose a

\footnotetext{
106 European Added Value Assessment, 'Combatting Violence Against Women' (European Parliament, November 2013) <http:// www.europarl.europa.eu/RegData/etudes/etudes/join/2013/ 504467/ IPOLJOIN ET(2013)504467 EN.pdf> accessed 6 December 2018, 3.

107 Anna Elomäki, The Economic Case for Gender Equality in the European Union: Selling Gender Equality to Decision-Makers and Neoliberalism to Women's Organizations' (2015) 22 European J ournal of Women's Studies 288, passim, esp 294.

108 ibid $295 \mathrm{ff}$.

109 In 2013, Helle Thorning-Schmidt's government adopted a law which required about 1,400 Denmark's largest companies to set targets for the percentage of women on boards. In 2017, $26 \%$ of board-members in Denmark were female. Ben Hamilton, 'Danish female board member numbers soar without the need for quotas', CPH Post Online (19 January 2917) $<\mathrm{http}: / /$ cphpost.dk/ news/ business/ danish-female-board-member-numbers-soar-without-the-needfor-quotas.html > accessed 25 May 2018.
} 
lower percentage as an aim - the Netherlands thus introduced a target figure of 30 $\% .110$ As a consequence, their domestic measures would have likely proven insufficient under the Directive. The possible negative impact on domestic measures was thus raised by a number of national parliaments. ${ }^{111}$ It is unsurprising mainly because the countries which adopted some measures had the strongest case to argue that action could be taken domestically.

The main objections coming from the national parliaments were about lack of evidence and timing. Both the Danish Folketinget and the Polish Senate noted that it was for the Commission to prove that action could not be taken domestically. As for timing, both UK Houses of Parliament, and both chambers of the Netherlands legislature in their joint letter, pointed out that it was too soon to know the results of domestic measures. For example, the House of Commons noted that 'many national measures have been introduced within the last year or two' and considered it 'too soon to write them off as ineffective.'112

In essence, the national parliaments were making the point that the fact that MSs have not yet achieved the aims, does not mean that they cannot. This is an interesting theoretical problem. I would argue that it would be not just too difficult to require the Commission to prove that something cannot happen, but actually methodologically impossible (if nothing else, one can at best assess trends for the future, but it is impossible to predict with certainty that something will never happen). This is, I believe, what the Commission meant by saying 113 that 'subsidiarity is not about the hypothetical possibility of reaching a certain policy objective'. Thus, at best, the Commission can infer the 'cannot' from past developments and make conclusions about future trends. Here, the Commission noted that (as of 2013):

EU-wide, $85 \%$ of non-executive board members and $91.1 \%$ of executive board members are men. Despite the intense public debate

\footnotetext{
$11030 \%$ is often cited in literature as the 'critical mass' when an organizational culture starts to shift. See discussion in House of Lords. European Union Committee, 'Women on Boards' (see note 13) 17-9. 111 Notably NL, UK, Sweden, Poland. Interestingly, this included France. Their domestic measures conformed to the Proposal's requirements (statutory target of $40 \%$ ), but the French Senate expressed worries about the procedural obligations under the Proposal.

112 A very similar point was made by the Netherlands legislatures.

113 This was reiterated in several response letters to the national parliaments, including the one to the Danish Folketinget, from which I cite.
} 
and some voluntary initiatives at a national and European level, the situation has not changed significantly in the past fewyears. ${ }^{114}$

Its projection was that without EU-wide action, 'the EU as a whole is not expected to even achieve $40 \%$ of women on boards by 2040 '. 115 To my mind, the Commission's assessment here is persuasive. The Commission noted that

In principle, Member States can improve the male/ female balance in boards of directors of their own volition. However, in reality, either the majority of EU Member States do not avail themselves of this opportunity, or the measures they do take are of such different nature that their results vary significantly. 116

To put this problem another way, it is essential to decide whether clear unwillingness ${ }^{117}$ of at least some MSs should be understood as inability ('cannot') which the EU can remedy. In our case, it has been clear that the CEE countries, with the notable exceptions of Slovenia and to some extent Poland, have not been addressing the problem at all and are not planning to do so in the foreseeable future. In this case, I would argue that the question of comparative effectiveness should be answered in favour of the EU, since some action is always more effective than no action (even if just in a proportion of the MSs). ${ }^{118}$

\section{Can the aim be better achieved at EU level? The internal market focus}

I mentioned above in section V.a that one of the dangers of relying on economic rationales is that when they do not turn out as expected, the legitimacy of a measure might be undermined. Relying on economic rationales entails yet another pitfall. Showing that companies would benefit from more women on company boards, but that they themselves completely fail to behave accordingly, would be an example of market failure. This is one of the reasons states would step up to regulate. Showing

\footnotetext{
114 Response letters to the Danish Folketinget.

115 Proposal for a Directive of the EP and of the Council on Improving the Gender Balance among Nonexecutive Directors of Companies Listed on Stock Exchanges and Related Measures (COM(2012) 614 final) 9 .

116 Commission's response to the Houses of Parliament of the Netherlands.

117 Willingness as a consideration is mentioned eg by Grainne De Burca, 'Reapprasing Subsidiarity's Significance after Amsterdam' Harvard Jean Monnet Working Paper 4 (1999) available at <https://jeanmonnetprogram.org/ archive/ papers/ 99/990701.html > accessed 31 May 2018.

118 See, similarly, Wieczorek, The Principle of Subsidiarity in EU Criminal Law' (see note 60) 87.
} 
that companies benefit from more women on company boards, on the other hand, supports an argument for leaving the matter to the market or to self-regulation. ${ }^{119}$ This logic extends to the legitimacy of EU intervention. If the measure was adopted on the assumption that the economic benefits were uncertain or negative, one would have a stronger case for central action. Expecting a trans-border flight of capital, from the countries which adopted some measures to those which have not, the EU could say that a harmonising policy was necessary at the EU level. There is even a precedent for this in the area of gender equality: the historic decision to include an equal pay provision in the Rome Treaty was meant to protect France, which already had this legislation, from comparative disadvantage. ${ }^{120}$ The UK's House of Commons indeed picked-up on this, saying that:

much of the analysis underpinning the Commission's proposal rests on the strength of the business case for introducing more diverse boards as a means of improving corporate governance and performance. There would therefore appear to be more, rather than less, reason for Member States to take action individually to promote greater gender balance on corporate boards as a means of securing competitive advantage. ${ }^{121}$

By insisting on the business case for the measure, the Commission thus weakened its subsidiarity case.

Aside from the business case as a basis for the measure in general, the Commission also framed the subsidiarity rationale specifically very much in crossborder, internal market terms:

The divergence or the absence of regulation at national level does not only lead to the discrepancies in the number of women among executive and nonexecutive directors and different rates of improvement across Member States, but also poses barriers to the internal market by imposing divergent corporate governance requirements on European listed companies. This

\footnotetext{
119 Especially since one can point to burgeoning self-regulation in some MSs, one can challenge the narrative of market failure and of the need for regulation.

120 Barnard (see note 83) 321-334.

${ }^{121}$ House of Commons. European Scrutiny Committee, 'Thirty-third Report of Session 2012- 13' (23 February 2013) <https:// publications.parliament.uk/pa/ cm201213/ cmselect/ cmeuleg/ 86xxxiii/ 86xxxiii.pdf> accessed 26 May 2018. A similar, but briefer, point was incorporated into its reasoned opinion.
} 
varied evolution of national legislations has led to a fragmentation of the legislative frameworks across the EU, which translates into inconsistent legal obligations of difficult comparability, confusion and higher costs for companies, investors and other stakeholders, and, ultimately, hinders the proper functioning of the internal market. 122

This sounds like the justification of an internal market measure based on Art 114 TFEU, not a gender equality one under Art 157 TFEU. And it is not surprising that the national parliaments were markedly sceptical. ${ }^{123}$ The Polish Sejm, for example, used the a fortiori argument, that basic issues' of 'company management structure' vary greatly (eg between monistic and dualistic ${ }^{124}$ set-up of boards). Thus if such a fundamental matter as appointing non-executive company directors or supervisory board does not pose a barrier to internal market growth, then neither do regulations pertaining to the participation of women in such boards. ${ }^{125}$

One cannot blame the national parliaments for not buying the internal market argument. Similarly to the overall justification of the measure through the benefits for companies, when the real concern is gender equality in economic decision-making, here too the emphasis on cross-border effects rings false. The measure is clearly concerned with domestic minimum standards. It is the question of whether and how the Commission could have presented a more convincing case, to which I now turn.

\section{NON-ECONOMIC, NON-CROSS-BORDER SUBSIDIARITY?}

Is the subsidiarity provision in the Treaty formulated in a way that only fits internal market logic? Does it thus work only for the economic sphere and cross-border situations? If the answer were yes, one would be left with two unsatisfactory options. One could, first, resign oneself to the discrepancy between what a measure, such as the current Proposal, actually aims at (setting minimum standards or improving

\footnotetext{
122 Commission's Explanatory Memorandum to the Proposal.

123 The Senate and House of Representatives of the Netherlands in their joint statement, the Swedish Riksdag, both UK Houses of Parliament.

${ }^{124}$ Some countries do and some do not distinguish between an executive and non-executive board. This variety in domestic corporate structure was for some, eg the Czech Chamber of Deputies, in itself a subsidiarity argument against the measure.

${ }^{125}$ At the same time, it could be argued that this minimal intrusion goes some way to fulfil the requirement of proportionality.
} 
individual rights domestically, without a clear cross-border benefit) and what it has to pay lip service to (cross-border dimension). This was the path the Commission chose. And, despite its internal inconsistency, this option is made possible by the fact that subsidiarity is legally an extremely weak principle, 126 achieving the thresholds of the yellow cards has proven difficult, ${ }^{127}$ and the Commission has been rather defiant about accepting the MSs' arguments. ${ }^{28}$ Having said this, a discrepancy between the stated benefit of transnational efficiency and actual expected impacts of the Proposal did give national parliaments unnecessary ammunition.

The second alternative, if only internal market rationales were permissible, would be to amend the Treaty and give the subsidiarity provision wording which would explicitly allow for non-cross-border, non-economic situations. This is, however, extremely unlikely.

Answering the questions in the negative gives a third alternative: arguing that given the current wording of the provision and content of the norm, the provision can already justify action in non-economic, non-cross-border situations. I believe this to be the case and I substantiate it below. In the following, after offering a typology of EU measures with respect to transnationality (section VI.a), I discuss subsidiarity in noncross border situations, focusing on how the 'scale and effects' requirement can be fulfilled (section VI.b), and then offer a few tentative observations on the specificity of fundamental rights measures (section VI.c).

\section{A. A typology of measures}

There are three types of measures, from the perspective of the existence of a 'crossborder' element: 1) measures with a transnational dimension; 2) 'federal' measures; and 3) measures addressing domestic situations. First, the creation and improvement of the internal market, with which much of EU action is concerned, has an obvious cross-border element. This goes, of course, especially for measures under Art 114 TFEU. Much of the litigation on the question of subsidiarity, and consequently the

\footnotetext{
126 The CJ EU has yet to invalidate a measure on its basis.

127 Only three have been issued so far.

128 For a summary of the three yellow card cases, see Fromage and Kreilinger (see note 14).
} 
academic debate, has focused on internal market situations. ${ }^{129}$ An example of such a measure was the proposal for a new posted workers directive, which led to the third 'yellow card' issued so far. ${ }^{130}$ In these situations, the cross-border element exists and the contentious subsidiarity issue tends to be whether differences in regulation between the MSs constitute barriers to the internal market. The predominance of the cross-border logic in subsidiarity reasoning has led some authors, even beyond the sphere of economic integration, such as in criminal law, to argue that a cross-border element is central and necessary to the delimitation of EU action. ${ }^{131}$ One could certainly argue that the 'presence of transnational aspects sets a presumption in favour of the supranational level'. ${ }^{132}$ But it does not mean that it is a necessary quality of a measure for the principle of subsidiarity to be fulfilled.

The second type of action is 'federal' in nature. An example here is the proposal for the creation of the European Public Prosecutor's Office (EPPO) ${ }^{133}$ or the Council Regulation on the Societas Europea. ${ }^{134}$ If one is establishing an institution which will operate on the European plane and fight against offenses affecting EU financial interests, as was the case with the former measure, or when one's aim is to facilitate the creation and functioning of multinational companies whose operation will be at the European level, as was the case with the latter, it is not too hard to see how a MSs action might prove insufficient and the EU level would be better. ${ }^{135}$ The presumption was the supranational level is even stronger here.

\footnotetext{
129 For a critical look at the case-law, see eg Stephen Weatherill, The Limits of Legislative Harmonisation Ten Years after Tobacco Advertising: How the Court's Case Law Has Become a “Drafting Guide"' (2011) 12 German Law J ournal 827.

130 The proposal was based on the specific competence within right to establishment (Art 53(1) TFEU). Proposal for a Directive of the EP and Council amending Directive 96/ 71/ EC concerning the posting of workers in the framework of the provision of services, COM/2016/0128 final - 2016/070 (COD), available at $<$ https:// eur-lex.europa.eu/legal-content/EN/TXT/ ?uri=COM\%3A2016\%3A128\%3AFIN> accessed on 30 May 2018. For a discussion, see Fromage and Kreilinger (see note 14).

131 Jacob Öberg, 'Subsidiarity and EU Procedural Criminal Law' (2015) 5 European Criminal Law Review 19.

132 Wieczorek, The Principle of Subsidiarity in EU Criminal Law' (see note 60) 80.

133 Proposal for a Council Regulation on the establishment of the European Public Prosecutor's Office, COM (2013) 534 final (July 17, 2013), available at <https:// eur-lex.europa.eu/legalcontent/EN/TXT/? uri=celex\%3A52013PC0534> accessed 31 May 2018.

134 Council Regulation (EC) No 2157/ 2001 of 8 October 2001 on the Statute for a European company (SE) [2001] OJ L 294/ 1.

135 Arguably, the yellow card troubles with the EPPO were down to very poor effort by the Commission to make the case for subsidiarity, rather than the case being a difficult one to make. Fromage and Kreilinger (see note 14) 132. For a detailed analysis, see Wieczorek, The EPPO Draft Regulation' (see note 14).
} 
Finally, there are measures which apply primary domestically, often setting a minimum standard of protection. This is, to my mind, the true nature of the current Proposal.

\section{B Comparative effectiveness in (purely) domestic situations}

In order to satisfy the requirements of subsidiarity, it should be the case that MSs cannot sufficiently achieve the aim and the EU has to be the better level for doing so, 'for reasons of the scale or effects of the proposed action'. The formulation 'scale or effects' is perhaps the one which most strongly appears to point to an internal market rationale. 'Scale', in particular, makes one think of the 'economies of scale' - the benefits businesses reap from access to a bigger, integrated market without barriers. But one can understand scale differently, as identifying the seriousness of the problem. In our case, it would be the fact that while women make up more than half the population, they - across the EU - constituted only roughly $15 \%$ of non-executive board members in the year the Proposal was presented. Bringing this proportion even to just $40 \%$ is a big task. The term could be understood as referring to the scale of the necessary change the measure aims to engender.

'Effects' are perhaps less immediately connected to a notion of the internal market. Even here, however, transnational regulation more clearly brings effects for the whole of the EU. But a similar argument can be made for domestic regulation. When left to their own devices, some MSs might reach the $40 \%$, some will go some way towards it, but many will not even try. In order to have effects in all of EU, one might need to regulate even domestic situations.

The reference to 'effects' also brings to mind effectiveness. The first problem is that we often think of effectiveness in economic terms. But that is not inevitable. The Oxford Living Dictionary defines 'effectiveness' as 'the degree to which something is successful in producing a desired result; success.' If the projections for the impact of the eventual Directive show marked increase in women's representation, especially compared to 'natural' development, they would fulfil the criterion of 'effect'. A second, more fundamental, issue is that the concept of effectiveness points to an empirical assessment of outcome rather than considerations of principle. Especially in the human rights field, one might be tempted to say that it is often right to adopt 
protections irrespective of the on-the-ground effect this will bring. This might be a strong argument for adoption of international treaties or indeed for giving an organisation like the EU the competence to act. But that is a question solved at the moment of creation, or the moment of application, of legal basis. In the context of deciding whether the EU should legislate on the basis of one of its fundamental rights competences, ie subsidiarity, however, the requirement of showing it will have 'effect' is perhaps not an illegitimate one.

\section{Subsidiarity and human rights}

A final question one might ask is whether there are specific subsidiarity considerations for fundamental rights measures. International human rights literature on subsidiarity has been quite careful about accepting the shifting of competence upward. Samantha Besson noted that it is a truism that 'states hav[e] the primary responsibility to secure human rights and international human rights institutions having only a supervisory function'.136 In international human rights law, these concerns are expressed in several doctrines: procedurally by the principle of 'exhaustion of domestic remedies', substantively, for example, by the doctrine of 'margin of appreciation', and remedially by mainly providing declaratory relief. 137

Her observations reflect the role of international human rights courts, however. They focus on 'negative' competence - the review of failure of a state to uphold a promised standard - rather than discuss the 'positive' competence of standard setting through legislation. In the case of the Proposal, we are not dealing with protecting infringed rights, but with positively ensuring their protection, via the use of legislative competence. It is partly because of the sui generis supranational nature of the EU that the latter question is unique to it. One way of looking at the issue is to say that if one is sceptical of giving too much power to courts providing external review of minimum standards, one should a fortiori be sceptical of shifting human rights competence to the centre. The counterargument is that the EU has created, or rather the MSs have created for it, certain specific competences to act in the sphere of fundamental rights.

\footnotetext{
136 Samantha Besson, 'Subsidiarity in International Human Rights Law—What is Subsidiary about Human Rights?' (2016) 61 The American J ournal of J urisprudence 69, 69.

137 ibid 79-83.
} 
This would support an argument of a differently configured subsidiarity than in general international human rights law.

It is then fruitful to look at the arguments why international public lawyers believe that action at the domestic level is generally more appropriate. Besson identifies two main reasons: a) a democratic one, having to do with superior participation and representation at lower levels, and b) epistemic, having to do with the lower level being close to the ground and thus better placed to evaluate. ${ }^{138}$ I would argue that both, but especially the first reason, is tested by the existence of 'internalities' and faces a challenge in particular when rights of minorities are at stake (women not being a numerical but a power minority).

The main reason why central governance is appropriate is one of 'externalities':

Whenever the effects of a given decision radiates beyond the deciding jurisdiction or when disaggregate decision-making leads to an incentive structure that tends to prevent outcomes that could be achieved by coordinated strategies, the decision should be moved to a higher level of governance. ${ }^{139}$

This is arguably the main reason for central regulation in the internal market.

But leaving regulation to the domestic level also raises a problem of 'internalities': 'majoritarian oppression, corruption, or minority capture that skew or undermine the democratic legitimacy of the political process of the constituent units', 140 etcetera. The possible failure of the domestic level to protect sub-groups is a well-known justification for having international human rights. And it is particularly salient for equality and discrimination rights, which specifically address the marginalisation of certain groups. Thus the protection and promotion of equality between men and women at the EU level can be a shield again domestic abuses (in the case of prohibition of discrimination) and even a sword that can demolish longstanding obstacles for the 'sub-group' of women (in the case of positive action).

138 ibid 94.

139 Halberstam (see note 60) 152.

140 ibid. 
The problem at hand can be seen as involving a two-fold majoritarian failure: marginalisation of women in democratic, political decision-making, as well as in economic decision-making. If domestic political processes do not address wide-spread gender inequality, this allows also the underrepresentation of women in the management and supervision of companies. This shows that MSs, some more than others, suffer from an 'internality' problem. It could then be argued that they 'cannot' achieve the aim themselves and the EU would be better placed to do so. In theory, the EU could be victim to the same 'male' majoritarian capture as the MSs. However, due to a long-standing pro-active approach to gender equality, it has achieved earlier and greater parity than most MSs. ${ }^{141}$ And it has also overcome the majoritarian capture in substance, by including substantive equality measures, mentioned above, aiming to limit the disadvantage faced by minorities.

\section{LESSONS?}

There appear to be two competing narratives relating to gender equality in the EU: one based on values, be they individual rights or democracy, another emphasizing the economic benefits of gender equality. This paper pointed out that making a business case for women's representation in economic decision-making, aside from its uncertain substantiation, paradoxically undermines the case for legislative intervention, irrespective of whether it is at the domestic or at EU level. It also observed that the use of internal market language and emphasis on cross-border issues rang false as a subsidiarity justification for the Proposal. This paper suggested that the Commission should have been ableto show that the 'objectives of the proposed action', namely critical-mass representation of women in economic decision-making, 'cannot be sufficiently achieved by the Member States' because of the unwillingness of several of the MSs to act. Moreover, that 'the scale' of the problem and the hoped-for 'effects' of an EU-wide 40 \% representation on non-executive company boards, would be better achieved at Union level'. Thus, domestic standard-setting aiming at the

\footnotetext{
${ }^{141}$ Nine out of 28 Commissioners are women, ie $32 \%$. The EU average is currently around $30 \%$. While some countries, such as France, have legally mandated 50 \% parity, in many countries, the proportion of women is considerably lower (Hungary is currently at only 7\%). As for the European Parliament, 36 $\%$ of MEPs were women in 2018, while the national average is around $30 \%$ here too. See charts available at European Institute for Gender Equality, Gender Statistics Database, Women and Men in Decision Making (Politics) <https:// eige.europa.eu/gender-statistics/dgs/browse/ wmidm/ wmidm_pol> accessed 6 December 2018.
} 
implementation of a fundamental right can be justified without resorting to economic, cross-border language and rationales.

The paper further noted that considering the focus of national parliaments' reasoned opinions and comments, it appears that two different conversations were necessary in presenting the Proposal: one on corporate governance and subsidiarity, mainly with some of the old Member States, and one on gender equality, with some of the new ones. It is doubtful, however, that making a principled gender-equality argument, rather than emphasising the economic benefits, would have aided the Proposal's reception in some of the new Member States. Given the strong neoliberal policy discourses in many CEE countries ${ }^{142}$ combined with marked scepticism towards gender equality and anti-discrimination law, ${ }^{143}$ one would expect a business case to have a better chance of succeeding than a rights-based justification. Nonetheless, without a conversation about the social reality of gender inequality, about existing barriers to women's advancement, and about how substantive equality and positive measures in particular can actually counteract them, this Proposal, as well as other equality measures, might continue to cause bemusement and face opposition from post-socialist members of the EU.

142 For a discussion, relating to the Czech case, see eg Havelková, Gender Equality (see note 11) 277-8. 143 ibid 225-76. 